\title{
Smoking Related Major- and Minor Salivary Gland Flow Rates, Xerostomia and Other Sicca Symptoms in Hungary
}

\author{
TAMAS DEMETER ${ }^{1}$ : (i https://orcid.org/0000-0003-3385-3344), \\ MELINDA PENZES ${ }^{2}$ :(D https://orcid.org/0000-0001-7396-4028); \\ ALEXANDRA KOVACS ${ }^{1}$ :(D https://orcid.org/0000-0001-5831-4983); \\ KATALIN KAROLYHAZY ${ }^{3}$ ( (D) https://orcid.org/0000-0002-4781-8251; , CSILLA ERDEI ${ }^{1}$, \\ VANDA ROXANA NIMIGEAN"4, VICTOR NIMIGEAN ${ }^{5}$, ANNA DEZSI ${ }^{1}$, \\ MELINDA SZEKELY' ${ }^{6}$, KRISZTINA MARTON ${ }^{1}$ ( (i) https://orcid.org/0000-0002-6525-2511)
}

${ }^{1}$ Department of General Dental Preclinical Practice, Faculty of Dentistry, Semmelweis University, Szentkiralyi u. 47., 1088, Budapest, Hungary

${ }^{2}$ Department of Public Health, Faculty of Medicine, Semmelweis University, Nagyvarad ter 4, 1089, Budapest, Hungary, ${ }^{3}$ Department of Prosthodontics, Semmelweis University, Faculty of Dentistry, Szentkiralyi u. 47.,1088, Budapest, Hungary, ${ }^{4}$ Carol Davila University of Medicine and Pharmacy in Bucharest, Faculty of Dental Medicine, Department of Oral Rehabilitation, 17-23 Calea Plevnei Str., 010221, Bucharest, Romania

${ }^{5}$ Carol Davila University of Medicine and Pharmacy in Bucharest, Faculty of Dental Medicine, Department of Anatomy, 17-23 Calea Plevnei Str., 010221, Bucharest, Romania

${ }^{6}$ George Emil Palade University of Medicine, Pharmacy, Science and Technology of Targu Mures, Faculty of Dental Medicine, Department of Morphology of Teeth and Dental Arches; Technology of Dental Prosthesis and Dental Materials, 38 Gh. Marinescu Str., 540139, Targu-Mures, Romania

Abstract. Objectives of this study were to explore the prevalence of subjective and objective dryness symptoms by smoking status in different age groups, to measure whole and minor saliva flow rates, and to evaluate the possible associations between salivary parameters, oral symptoms and the intensity of smoking in a sample of Hungarian adults. Repeated cross-sectional studies were conducted in 2003 (n=600) and 2014-2018 (n=301) among Hungarian adults visiting regional outpatient dental clinics of their residence where dentist interviewed them about their subjective sicca symptoms and cigarette smoking habits (non-smoker - NS, light smoker - LIS, moderate or heavy smoker-MHS), and measured unstimulated whole saliva flow rate (UWS), palatal-and labial minor saliva flow rates to assess xerostomia objectively. The severity of xerostomia was significantly higher in among 30-39year-old male smokers (44.8\%; $p=0.001)$, and among 18-29-year-old female smokers (52.9\%; $p=0.013)$, compared to their non-smoker counterparts $(6.7 \%$ and $27.1 \%$, respectively). UWS flow rate was significantly lower among 18-29-year-old MHS females compared to NS and LIS females in the same age group ( $p=0.019, p=0.015$, respectively). Significantly increased palatal saliva flow rate was registered among 30-39-year-old MHS males compared to their NS counterparts ( $p=0.046)$. Our study highlighted that high intensity of smoking may cause xerostomia, a decrease in the UWS flow rate, and an increase in palatal saliva flow rate in some age groups, however, other sicca symptoms were mostly unrelated to the presence of dry mouth.

Keywords: cigarette smoking, oral dryness, unstimulated whole saliva, minor salivary gland

\section{Introduction}

Functions of saliva has an important role in regulation and maintenance of integrity of the oral tissues as well as oral and general health monitoring, including e.g. the use of salivary hormone assays in various fields of medicine and research [1,2]. Hyposalivation is an objective finding of a decreased saliva production, while xerostomia (dry mouth) is a subjective feeling of oral dryness. Dry mouth,

*email:vandanimigean@yahoo.com 
however, might be the clinical expression of severely decreased whole saliva flow rate $[3,4]$. The normal unstimulated whole saliva (UWS) flow rate is around $0.3 \mathrm{~mL} / \mathrm{min}$ [4]. UWS flow rate $\leq 0.1$ $\mathrm{ml} / \mathrm{min}$ is regarded as hyposalivation. However, xerostomia, per se, is not always accompanied by reduced salivation. Nevertheless, the absence of xerostomia does not necessarily mean that there is adequate salivary secretion $[5,6]$.

The prevalence of xerostomia in the population ranges from 5.5 to $46 \%$ [7]. Xerogenic factors could be systemic conditions and/or diseases (e.g., diabetes, irradiation therapy of the head and neck region, graft-versus-host disease, autoimmune diseases, depression, anxiety, stress, or malnutrition) and the use of several drugs $[4,7,8]$. Xerostomia is seldom a solitary symptom. When present for an extended period of time, it induces a wide variety of other oral sicca symptoms, like burning mouth, cheilitis, glossodynia, difficulty with eating dry foods, dysphagia, candidiasis, dysphonia and dysgeusia [4,5]. Moreover, numerous non-oral clinical signs can be associated with xerostomia as possible signs of generalized exocrinopathy, including ophtalmological (keratoconjunctivitis sicca), dermal (xeroderma), nasal, gynaecological dryness symptoms and fatigue, as a manifestation of sicca syndrome [4,5,9-11].

Existing studies indicate that tobacco use may have numerous unfavorable impact on oral health, including malodor, tooth discoloration, increased risk for caries, leukoplakia and oral cancer, delayed healing process in the oral cavity, and failure of dental implants [12]. The effect of smoking onto salivation and its possible association with dry mouth has controversial results in the literature. Toxic chemicals in cigarette smoke can cause structural and functional changes in the saliva, which is the first biological fluid exposed to cigarette smoke [13,14]. In an experimental study in Wistar rats, environmental tobacco smoke exposure led to substantial structural changes in the salivary glands which could significantly affect function [15]. Petrušić et al. found significant difference in the quality of human saliva, that is, the majority of smokers had thick saliva, while non-smokers had thin and watery saliva [16].

Some authors found positive correlation between smoking and salivary parameters, especially in the short term: mechanical, chemical and thermal stimulation of salivary glands during smoking can increase the amount of saliva [17,18]. Some studies reported that cigarette smoking can increase parotid saliva flow rate in humans $[19,20]$, while others found increased salivation of the sublingual gland in rats, following cellular nicotinic receptor activation [21]. A recent study suggests that nicotine may enhance parotid salivation via increasing the intracellular $\mathrm{Ca}^{2+}$ concentration [22]. Regarding minor salivary gland secretions, Eliasson et al. found increased secretion (by 27\%) among smokers which may be due to the local irritant effect of tobacco smoke resulting in an increased glandular output [23]. Moreover, in a Swedish study assessing dental status and smoking of the study population, male smokers had significantly higher stimulated salivary flow rates than male non-smokers; however, smokers reported more frequently dry mouth [24].

On the other hand, other researchers could not detect any effect of smoking on salivary parameters and oral dryness symptoms, controlling for other conditions like alcohol consumption, dental status or obesity $[3,25,26]$.

Several studies showed negative effects of smoking onto the subjective sicca symptoms and salivation. Anttila et al. found significant association between the subjective sensation of dry mouth and low unstimulated saliva flow rate in regular smokers [27]. Long-term smoking may adversely affect the function of the salivary glands which reflects in decreased amount and poorer quality of saliva [16,28]. Long-term use of tobacco especially smokeless forms may also cause significant decrease in the whole saliva flow rate and alter its $p \mathrm{H}$ towards acidic direction $[18,29]$. Regarding xerostomia, studies consistently found that current cigarette smoking contributes to the subjective feeling of oral dryness [30-32], although its association with gender, age and smoking intensity is still unclear. 
There is scarce data in the literature of investigating the correlation between the intensity of smoking with salivary parameters and dryness symptoms. Additionally, in the current publications there is a limited evidence about the possible intra- and extra oral xerogenic effects of tobacco smoking. Therefore, the aims of this present study were to assess the prevalence of both subjective and objective dryness symptoms by smoking status in different age groups, to measure whole and minor saliva flow rates, and to evaluate the possible associations between salivary parameters, oral symptoms and the intensity of smoking.

\section{Material and methods}

Repeated cross-sectional studies were conducted in $2003(\mathrm{n}=600)$ and 2014-2018 $(\mathrm{n}=301)$ among Hungarian adults visiting regional outpatient dental clinics of their residence. Participants were randomly selected by age and gender following the current regional distribution pattern of the Hungarian Statistical Office. All participants were inhabitants of the urban and rural areas of different regions in Hungary. Data were collected via personal interview and clinical examinations by dentists. Smokers using other tobacco products than conventional factory-made or roll-your-own cigarettes were excluded from the studies. Mean age of the aggregated sample (58.3\% females) was $46 \pm 16$ years (range from 18 to 92 years).

This study has been approved by the Regional and Institutional Committee of Science and Research Ethics of Semmelweis University (No. 104/2003). All participants provided informed written consent to the study.

Subjective sicca symptoms and cigarette smoking habits were assessed by a questionnaire during personal interview with a dentist right before a clinical examination. The questionnaire was developed for this study and included items about participants' socio-demographics (age - categorized as 18-29, $30-39,40-59$, and 60+ year-old age groups; gender), subjective symptoms of oral dryness and other related sicca symptoms (14 items for males and 16 items for females - table 1 and table 2 [5] - with response options severe/moderate/mild/no symptoms collapsed into dichotomous variable - yes/no for some analyses), and cigarette smoking status. Current smokers were defined as those who have smoked every day in the past 30 days. Regarding smoking intensity (the number of cigarettes smoked per day - CPD), participants were categorized into moderate or heavy smoker (MHS - smoked $\geq 11$ CPD), light smoker (LIS - smoked 1-10 CPD), and non-smoker (NS) groups [33]. After completing the questionnaire, dental clinical examinations were conducted of which the measurement of unstimulated whole saliva (UWS) flow rate and minor salivary gland secretions were included in this present study. Collection of UWS was described previously by Márton et al. (2008) [5]. UWS flow rate was expressed in $\mathrm{ml} / \mathrm{min}$ (which is nearly equivalent to $\mathrm{g} / \mathrm{min}$ ). A salivary secretion rate of 0.1 $\mathrm{ml} / \mathrm{min}$ or less was considered as an objective sign of salivary hypofunction (hyposalivation). Palataland labial minor salivary gland flow rates were measured with the Periotron 8000 (Oraflow Inc., Amityville, USA) device, using filter paper discs (Saliva paper, Oraflow Inc., Amityville, USA) with a standard diameter of $8 \mathrm{~mm}$ (area: $0.5 \mathrm{~cm}^{2}$ ). Measurements were carried out for $30 \mathrm{~s}$ on three main sites, according to the distribution of the minor salivary glands in the oral cavity [34]. The discs were placed individually on both sides of the hard palate in the region of the upper first molars, $15 \mathrm{~mm}$ palatally from the gingival margin (in case of palatal saliva flow), and on the oral surface of the lower lip (in case of labial saliva flow), $3 \mathrm{~mm}$ from the outer border of the lower labial mucosa, near the midline. The sites were previously dried with cotton gauze. After each measurement, paper discs were placed between the two electrodes of the Periotron device. The exact quantity of the absorbed saliva was recorded based on the electromagnetic properties of the absorbed micro-moisture. The Periotron readings were then transformed into $\mu 1 / \mathrm{cm}^{2} / \mathrm{min}$ values according to the previous calibration of the device with known quantities of distilled water [35-37]. 


\section{Statistical analysis}

Descriptive characteristics of the sample, subjective sicca symptoms, UWS and minor salivary gland flow rates are presented in percentages, means, and standard deviations (SD). Independent samples t-test, one-way ANOVA, and $\chi^{2}$ test were used to test associations. All analyzes were performed using IBM SPSS version 24.0 software, and significance level was accepted at $\mathrm{p}<0.05$.

\section{Results and discussions}

In overall, $35.9 \%$ of the sample was current smoker $(43.4 \%$ of males and $30.5 \%$ of females, $\mathrm{p}<0.001)$. The intensity of smoking in different age groups by gender is presented in figure 1 . Data show that $51.3 \%$ of female smokers and $60.7 \%$ of male smokers were MHS. Among females, daily smoking prevalence and intensity were highest in the 40-59-year-old age group $(38.0 \%$ and $20.9 \%$, respectively); while among males, the prevalence was highest in the 18-29-year-old age group (60.4\%), and intensity in the 30-39-year-old age group (38.3\%).

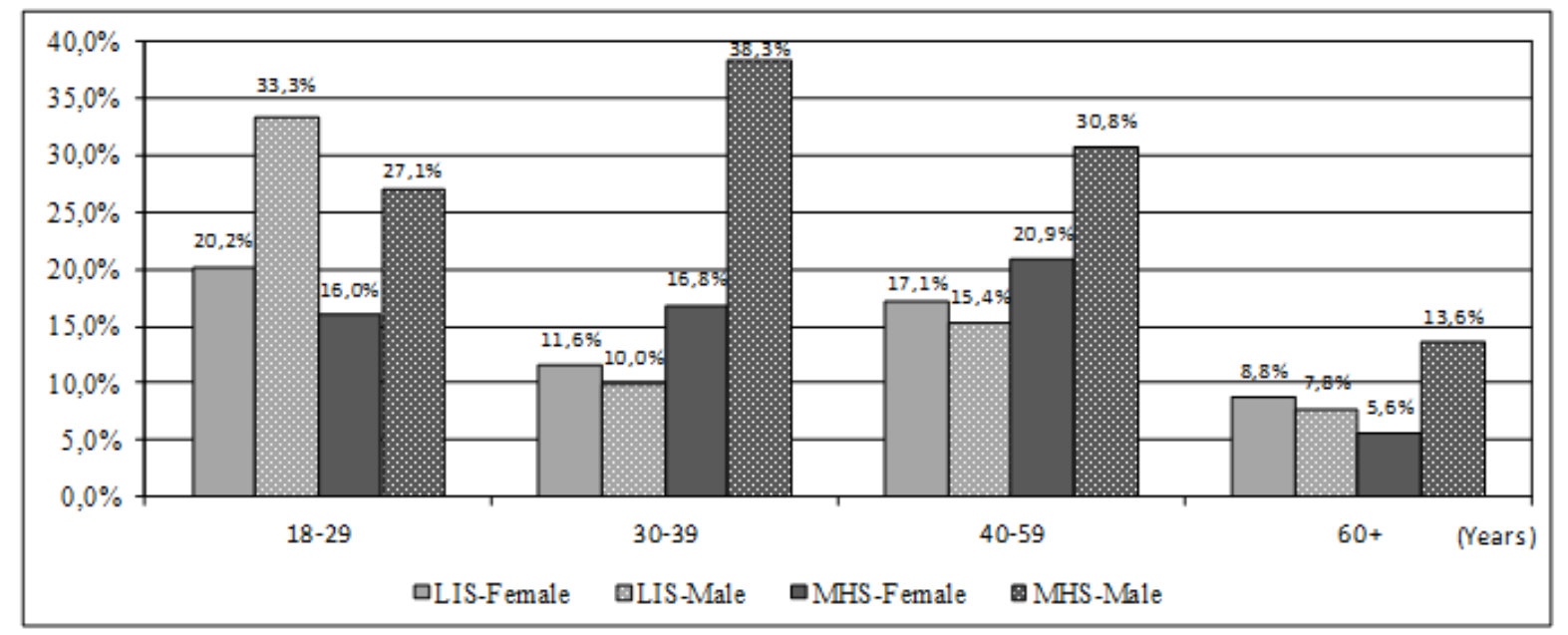

LIS=light smoker, MHS=moderate or heavy smoker

Figure 1. Intensity of smoking by gender and age groups

Table 1. Prevalence of intra- and extraoral sicca symptoms by smoking status in hungarian males

\begin{tabular}{|c|c|c|c|c|c|c|c|c|c|c|}
\hline \multirow{3}{*}{ Subjective symptoms in \% } & \multicolumn{10}{|c|}{ Age groups (years) } \\
\hline & \multicolumn{2}{|c|}{$\begin{array}{c}18-29 \\
(n=96)\end{array}$} & \multicolumn{2}{|c|}{$\begin{array}{c}30-39 \\
(n=60)\end{array}$} & \multicolumn{2}{|c|}{$\begin{array}{c}40-59 \\
(n=117)\end{array}$} & \multicolumn{2}{|c|}{$\begin{array}{c}60+ \\
(n=103)\end{array}$} & \multicolumn{2}{|c|}{$\begin{array}{c}\text { Total } \\
(n=376)\end{array}$} \\
\hline & $\begin{array}{c}\text { NS } \\
(n=38)\end{array}$ & $\underset{(n=58)}{S}$ & $\begin{array}{c}\text { NS } \\
(n=31)\end{array}$ & $\underset{(n=29)}{S}$ & $\begin{array}{c}\text { NS } \\
(n=63)\end{array}$ & $\underset{(n=54)}{S}$ & $\underset{(n=81)}{N S}$ & $\underset{(n=22)}{S}$ & $\begin{array}{c}\mathrm{NS} \\
(\mathrm{n}=\mathbf{2 1 3})\end{array}$ & $\begin{array}{c}S \\
(n=163)\end{array}$ \\
\hline 1. Xerostomia & 28.2 & 29.3 & 6.7 & $44.8 * *$ & 22.2 & 31.5 & 42.0 & 50.0 & 28.6 & 35.6 \\
\hline 2. Dysphagia & 12.8 & 10.3 & 10.0 & 13.8 & 11.1 & 18.5 & 12.4 & $36.4 *$ & 11.7 & 17.2 \\
\hline 3.Glossodynia, burning mouth & 10.3 & 6.9 & 13.3 & 3.5 & 7.9 & 13.0 & 1.2 & 9.1 & 6.6 & 9.2 \\
\hline 4. Dysphonia & 35.9 & 46.6 & 26.7 & 27.6 & 25.4 & 33.3 & 27.2 & 18.2 & 28.2 & 35.0 \\
\hline 5. Dysgeusia & 5.1 & 10.3 & 3.3 & 10.3 & 6.4 & 13.0 & 12.4 & 4.6 & 8.0 & 10.4 \\
\hline 6. Reduced saliva feeling & 5.1 & 12.1 & 3.3 & 17.2 & 9.5 & 7.4 & 22.2 & 9.1 & 12.7 & 11.0 \\
\hline 7. Mucous saliva & 18.0 & 29.3 & 16.7 & 24.1 & 22.2 & 18.5 & 18.5 & 9.1 & 19.3 & 22.1 \\
\hline 8. Increased caries activity & 64.1 & 74.1 & 66.7 & 79.3 & 68.3 & 77.8 & 66.7 & 72.7 & 66.7 & 76.7 \\
\hline
\end{tabular}




\section{Revista de Chimie}

https://revistadechimie.ro

https://doi.org/10.37358/Rev. Chim.1949

\begin{tabular}{|l|c|c|c|c|c|c|c|c|c|c|}
\hline 9. Nasal dryness & 15.4 & 32.8 & 40.0 & 41.4 & 25.4 & 31.5 & 29.6 & 40.9 & 27.2 & 35.6 \\
\hline 10. Dryness of the eyes & 28.2 & 20.7 & 13.3 & 17.2 & 22.2 & 16.7 & 19.8 & 13.6 & 21.1 & 17.8 \\
\hline 11. Itching, burning of the eyes & 30.8 & 27.6 & 23.3 & 44.8 & 30.2 & 37.0 & 38.3 & 40.9 & 32.4 & 35.0 \\
\hline 12. Light sensitivity & 43.6 & 34.5 & 36.7 & 51.7 & 36.5 & 37.0 & 44.4 & 63.6 & 40.9 & 41.7 \\
\hline 13. Xeroderma & 30.8 & 48.3 & 43.3 & 44.8 & 39.7 & 42.6 & 49.4 & 54.6 & 42.3 & 47.2 \\
\hline 14. Fatigue & 59.0 & 69.0 & $\mathbf{2 6 . 7}$ & $\mathbf{7 2 . 4} * *$ & 50.8 & 53.7 & 60.5 & 50.0 & 52.6 & 62.0 \\
\hline
\end{tabular}

Bold letters indicate significant differences between smokers and non-smokers. S: smokers, NS: non-smokers. ${ }^{*} \mathrm{p}<0.05 ;{ }^{* *} \mathrm{p}<0.001$

Table 2. Prevalence of intra- and extraoral sicca symptoms by smoking status in hungarian females

\begin{tabular}{|c|c|c|c|c|c|c|c|c|c|c|}
\hline \multirow{3}{*}{ Subjective symptoms in \% } & \multicolumn{10}{|c|}{ Age groups (years) } \\
\hline & \multicolumn{2}{|c|}{$\begin{array}{l}18-29 \\
(n=94)\end{array}$} & \multicolumn{2}{|c|}{$\begin{array}{r}30-39 \\
(n=95)\end{array}$} & \multicolumn{2}{|c|}{$\begin{array}{c}40-59 \\
(n=211)\end{array}$} & \multicolumn{2}{|c|}{$\begin{array}{c}60+ \\
(n=125)\end{array}$} & \multicolumn{2}{|c|}{$\begin{array}{c}\text { Total } \\
(\mathbf{n}=\mathbf{5 2 5})\end{array}$} \\
\hline & $\begin{array}{c}\text { NS } \\
(n=59)\end{array}$ & $\underset{(n=35)}{S}$ & $\begin{array}{c}\text { NS } \\
(n=68)\end{array}$ & $\underset{(n=27)}{S}$ & $\begin{array}{c}\mathrm{NS} \\
(\mathrm{n}=131)\end{array}$ & $\underset{(n=80)}{S}$ & $\begin{array}{c}\mathrm{NS} \\
(\mathrm{n}=107)\end{array}$ & $\underset{(n=18)}{S}$ & $\underset{\substack{N S \\
(n=365)}}{N}$ & $\begin{array}{c}S \\
(n=160)\end{array}$ \\
\hline 1. Xerostomia & 27.1 & $52.9 *$ & 39.7 & 25.9 & 43.5 & 43.8 & 52.3 & 38.9 & 42.7 & 41.9 \\
\hline 2. Dysphagia & 10.2 & 20.6 & 13.2 & 14.8 & 22.9 & 25.0 & 16.8 & 22.2 & 17.3 & 21.3 \\
\hline 3.Glossodynia, burning mouth & 6.8 & 8.8 & 5.9 & 7.4 & 11.5 & 12.5 & 6.5 & 11.1 & 8.2 & 10.0 \\
\hline 4. Dysphonia & 50.9 & 47.1 & 42.7 & 25.9 & 34.4 & 41.3 & 38.3 & 61.1 & 39.7 & 41.9 \\
\hline 5. Dysgeusia & 6.8 & 5.9 & 7.4 & 7.4 & 14.5 & 13.8 & 10.3 & $27.8 *$ & 10.7 & 12.5 \\
\hline 6. Reduced saliva feeling & 10.2 & 5.9 & 13.2 & 14.8 & 17.6 & 15.0 & 15.0 & 33.3 & 14.8 & 15.0 \\
\hline 7. Mucous saliva & 20.3 & 32.4 & 17.7 & 14.8 & 10.7 & 16.3 & 12.2 & 16.7 & 14.0 & 19.4 \\
\hline 8. Increased caries activity & 62.7 & $85.3 *$ & 82.4 & 77.8 & 74.8 & 75.0 & 64.5 & 77.8 & 71.2 & 78.1 \\
\hline 9. Nasal dryness & 40.7 & 32.4 & 29.4 & 44.4 & 42.0 & 31.3 & 33.6 & 44.4 & 37.0 & 34.4 \\
\hline 10. Dryness of the eyes & 25.4 & 23.5 & 29.4 & 22.2 & 36.6 & 33.8 & 43.9 & $16.7 *$ & 35.6 & 27.5 \\
\hline 11. Itching, burning of the eyes & 49.2 & 47.1 & 36.8 & 37.0 & 49.6 & 41.3 & 55.1 & $27.8 *$ & 48.8 & 40.0 \\
\hline 12. Light sensitivity & 54.2 & 44.1 & 52.9 & 40.7 & 60.3 & 65.0 & 50.5 & 38.9 & 55.1 & 53.1 \\
\hline 13. Xeroderma & 72.9 & 79.4 & 70.6 & 70.4 & 71.0 & 68.8 & 79.4 & 72.2 & 73.7 & 71.3 \\
\hline 14. Vaginal dryness & 6.8 & 8.8 & 11.8 & 3.7 & 22.9 & 15.0 & 22.4 & 11.1 & 18.1 & $11.3 *$ \\
\hline $\begin{array}{l}\text { 15. Vaginal itching, burning, } \\
\text { fungal infections }\end{array}$ & 15.3 & 26.5 & 25.0 & 14.8 & 18.3 & 11.3 & 12.2 & 5.6 & 17.3 & 13.8 \\
\hline 16. Fatigue & 69.5 & 79.4 & 70.6 & 55.6 & 69.5 & 76.3 & 71.0 & 61.1 & 70.1 & 71.9 \\
\hline
\end{tabular}

Among smokers, $35.6 \%$ of males and $41.9 \%$ of the females reported subjective oral dryness (xerostomia), and $7.4 \%$ and $9.4 \%$ indicated it to be severe, respectively (table 1 and 2). These results did not differ significantly from related results of non-smokers $(28.6 \%, 42.7 \%, 5.6 \%$ and $7.4 \%$, 
respectively). Among males, subjective feeling of fatigue was significantly higher in 30-39-year-old smokers compared to non-smokers $(\mathrm{p}=0.001)$, while dysphagia was more common in $60+-$ year-old smokers compared to non-smokers $(\mathrm{p}=0.008)$. Among females, increased caries activity was reported in significantly higher proportion by 18-29-year-old smokers than by non-smokers in the same age group $(\mathrm{p}=0.021)$. Compared to $60+$-year-old non-smoker females, smoker females in the same age group indicated in significantly higher proportion to have dysgeusia (have difficulty with taste, $\mathrm{p}=0.040$ ), xerophtalmia ( $\mathrm{p}=0.030)$, and itching or burning sensation in their eyes $(\mathrm{p}=0.032)$. Regardless of age groups, greater proportion of non-smokers reported suffering from vaginal dryness than smokers $(\mathrm{p}=0.049)$. Other subjective sicca symptoms did not show significant differences between smoker and non-smoker males and females. Regarding the severity of xerostomia in different age groups, a significant increase was detected in subjective xerostomia among male smokers in the 3039 -year-old age group (44.8\%; $\mathrm{p}=0.001$ ), and among female smokers in the 18-29-year-old age group (52.9\%; $\mathrm{p}=0.013)$, compared to their non-smoker counterparts $(6.7 \%$ and $27.1 \%$, respectively) (Figure 2).

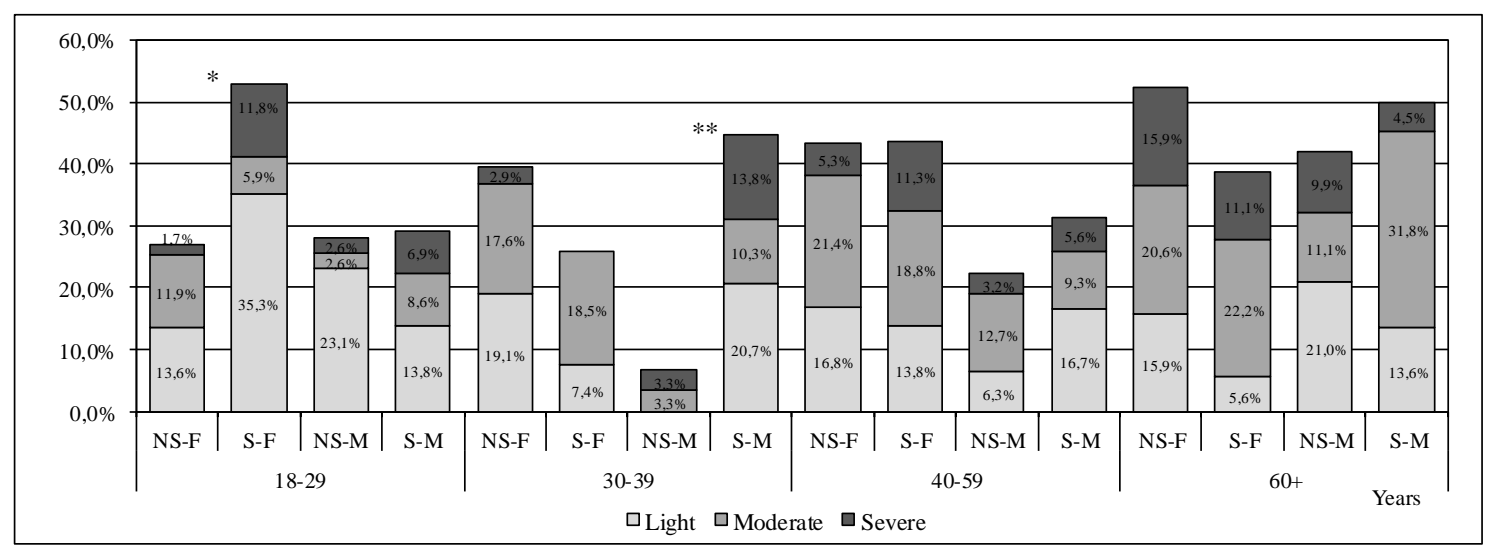

NS-F=non-smoker females, S-F=smoker females, NS-M=non-smoker males, $\mathrm{S}-\mathrm{M}=$ smoker males. ${ }^{*} \mathrm{p}<0.05,{ }^{*} \mathrm{p}<0.001$

Figure 2. Prevalence of light, moderate and severe xerostomia according to smoking intensity among females and males in different age groups

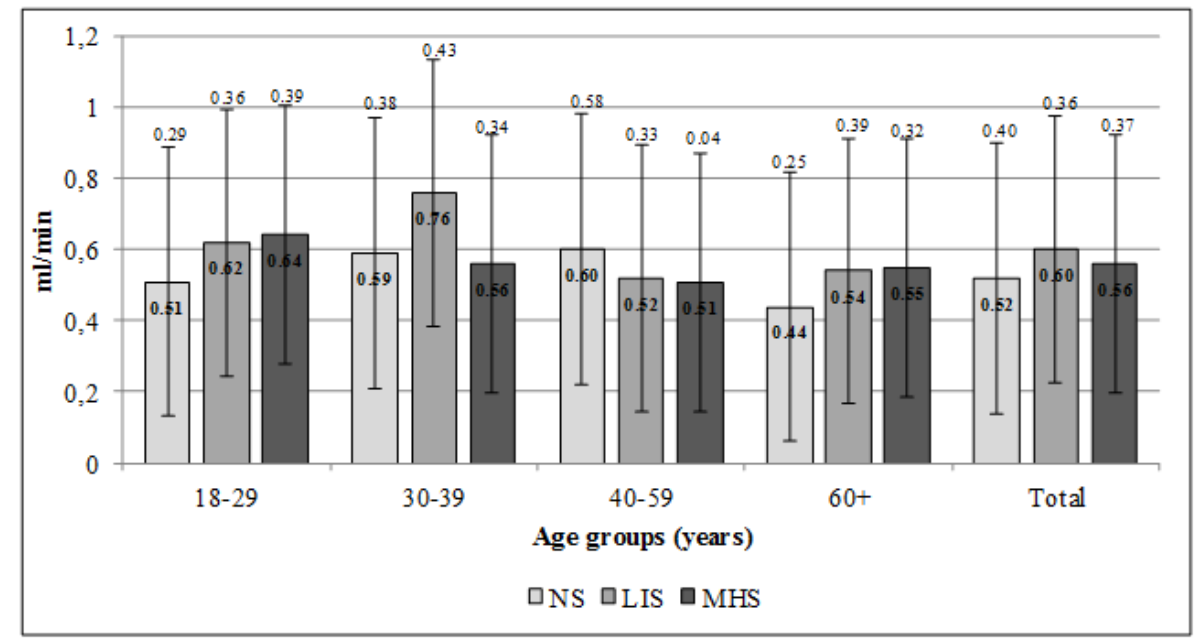

Means and standard deviations are presented. NS=non-smoker; LIS=light smoker; MHS=moderate or heavy smoker

Figure 3. Unstimulated whole saliva (uws) flow rates according to smoking intensity in males in different age groups 


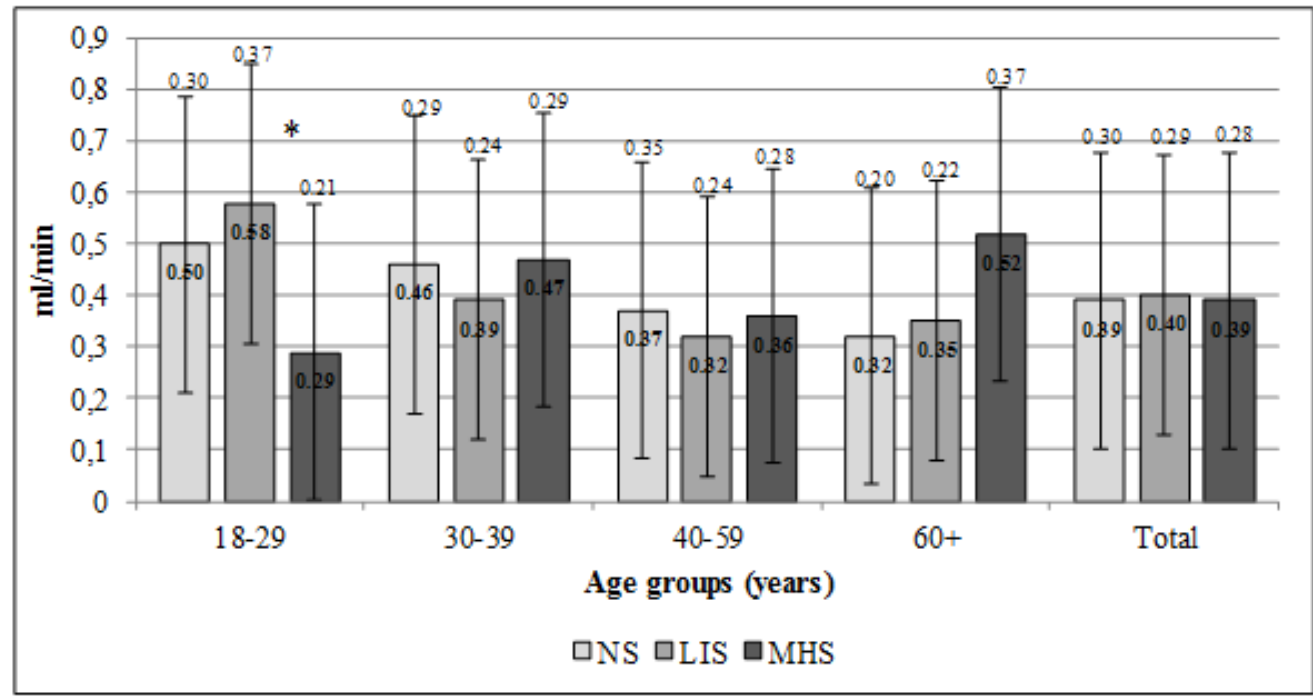

Means and standard deviations are presented. NS=non-smoker; LIS=light smoker; MHS=moderate or heavy smoker. *p $<0.05$

Figure 4. Unstimulated whole saliva (uws) flow rates according to smoking intensity in females in different age groups

Among males, UWS flow rates did not differed significantly according to smoking intensity either in the overall male sample or by considering age groups (Figure 3). In the overall female sample, there was no detectable significant difference in UWS flow rates concerning smoking intensity. However, we measured significantly lower UWS flow rate in the 18-29-year-old MHS female sample compared to NS and LIS females in the same age group ( $\mathrm{p}=0.019 ; \mathrm{p}=0.015$, respectively) (Figure 4).

When measuring minor salivary gland flow rates, significantly higher palatal saliva flow rate was registered among 30-39-year-old MHS males compared to their NS counterparts ( $\mathrm{p}=0.046)$ (Figure 5). The labial saliva flow rate of the overall MHS female sample was significantly lower compared to NS females $(\mathrm{p}=0.046)$, whereas LIS females in the age group of $60+$ had significantly lower palatal saliva flow rate than NS females in the same age group $(p=0.004)$ (Figure 6). No other significant differences have been recorded in the salivary parameters of NS, LIS and MHS males and females in other age groups.

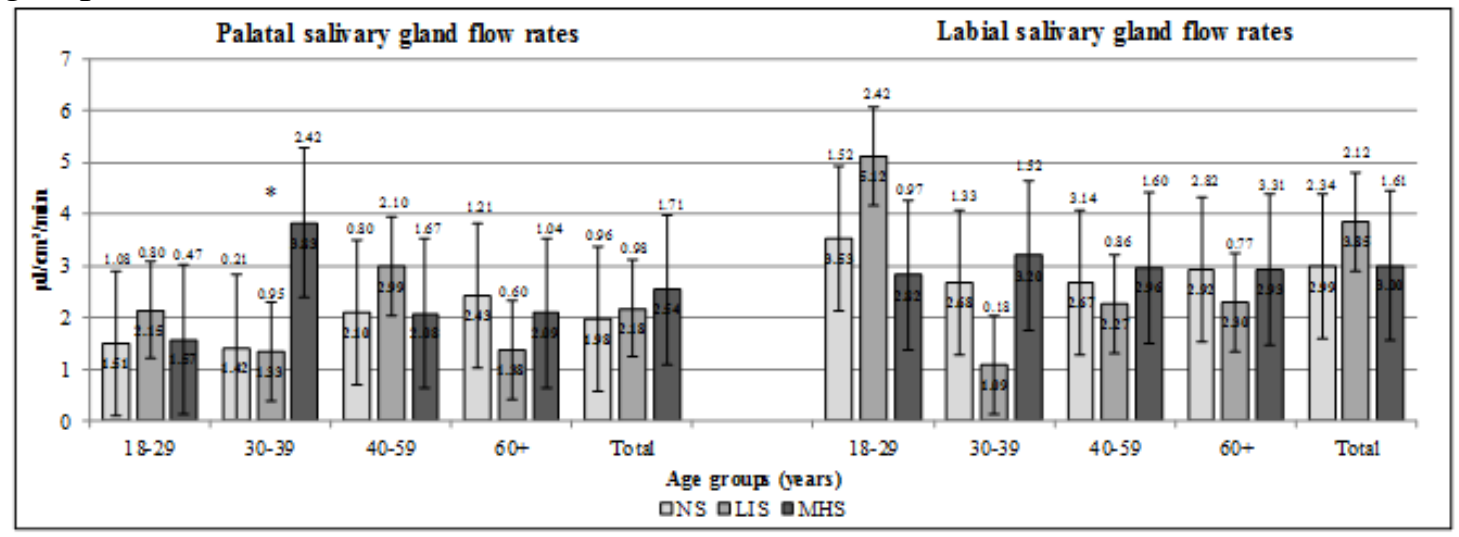

Means and standard deviations are presented. NS=Non-smoker; LIS=Light smoker; MHS=Moderate or heavy smoker. *p $=0.05$

Figure 5. Minor salivary gland flow rates in males in different age groups

Hyposalivation (UWS flow rate $\leq 0.1 \mathrm{ml} / \mathrm{min}$ ) was detected in $9.0 \%$ of non-smoker and $11.3 \%$ of smoker females, and $4.2 \%$ of non-smoker and $1.2 \%$ of smoker males (table 3 ). None of these results 
differed significantly. Sixty-two out of all 901 patients (6.9\%) showed hyposalivation. Most of them $(82.3 \%)$ were females, and $48.4 \%$ of them belonged to the age group of $40-59$ years.

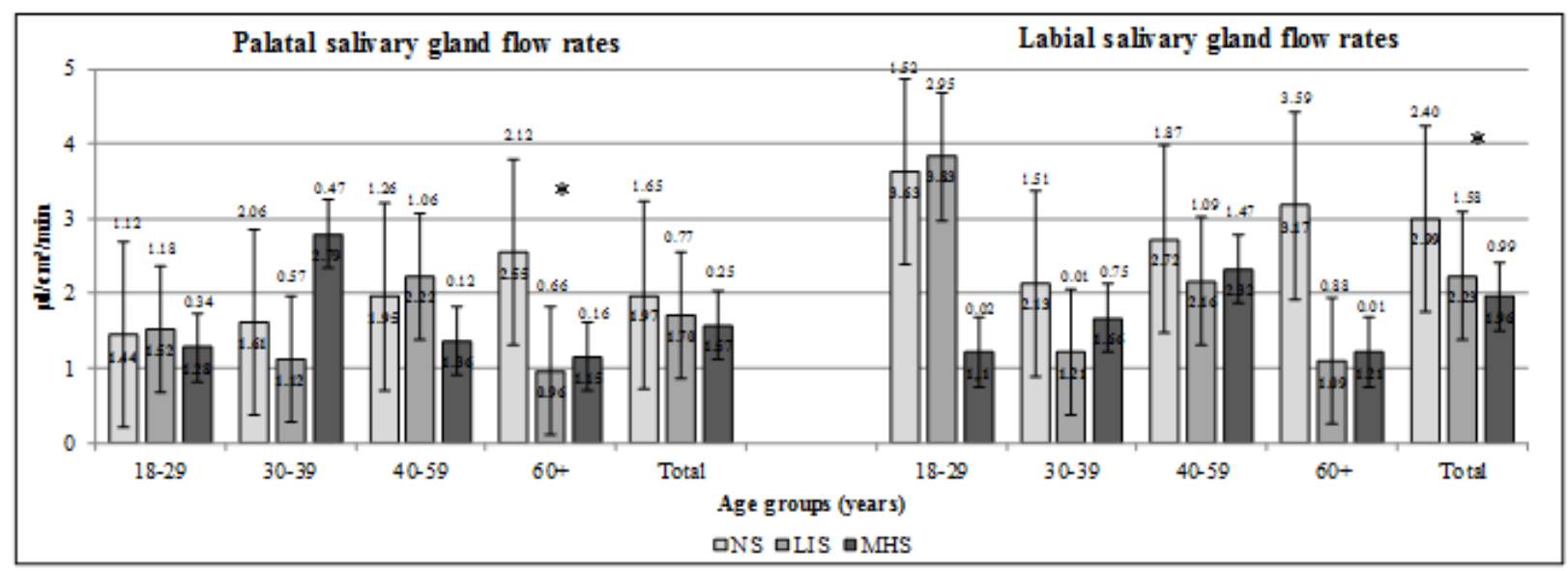

Means and standard deviations are presented. NS=Non-smoker; LIS=Light smoker; MHS=Moderate or heavy smoker; ${ }^{*} \mathrm{p}$ $=0.05$

Figure 6. Minor salivary gland flow rates in females in different age groups

Table 3. Prevalence of hyposalivation by smoking status in different age groups

\begin{tabular}{|c|c|c|c|c|c|c|c|c|c|c|}
\hline \multirow{3}{*}{$\begin{array}{c}\text { Prevalence of hyposalivation in } \\
\% \% \\
\text { (UWS flow rate } \leq 0.1 \mathrm{~mL} / \mathrm{min} \text { ); } \\
\mathrm{n}=901\end{array}$} & \multicolumn{10}{|c|}{ Age groups } \\
\hline & \multicolumn{2}{|c|}{$18-29$} & \multicolumn{2}{|c|}{$30-39$} & \multicolumn{2}{|c|}{$40-59$} & \multicolumn{2}{|c|}{$60+$} & \multicolumn{2}{|c|}{ Total } \\
\hline & NS & $\mathbf{S}$ & NS & $\mathrm{s}$ & NS & $\mathrm{S}$ & NS & $\mathrm{s}$ & NS & $\mathbf{S}$ \\
\hline Females $(\mathrm{n}=\mathbf{5 2 5})$ & 1.7 & 2.9 & 7.4 & 3.7 & 13.0 & 16.3 & 9.4 & 16.7 & 9.0 & 11.3 \\
\hline Males $(n=376)$ & 0.0 & 1.7 & 0.0 & 0.0 & 7.9 & 0.0 & 4.9 & 4.6 & 4.2 & 1.2 \\
\hline
\end{tabular}

UWS: unstimulated whole saliva.

In our sample, the prevalence of smoking and intensity of smoking was higher than related national data based on representative samples of Hungarian adults [38]. A possible explanation for overrepresentation of smokers in our sample could be that smokers, particularly heavy smokers have poorer oral hygiene and increased risk for periodontal diseases [39], therefore they may attend more frequently to dental health service.

In our sample, smokers in the youngest female age group and in the 30-39-year-old male age group complained significantly more about feeling of dry mouth, therefore, it is suspected that a positive correlation might exist between the intensity of smoking and xerostomia among younger adults.

Although UWS flow rate was not decreased significantly in any smoker male age groups, palatal saliva flow rate increased significantly in the 30-39-year-old male MHS group. This increase can either be the consequence of an initial compensatory mechanism of the palatal minor salivary glands to xerostomia, or the other reason might be the direct stimulating effect of the high level of tobacco smoke to the palatal region's glands. Eliasson et al. obtained similar results, and he suggested the local irritative effect of tobacco smoking onto the minor salivary glands as it increased their output [23].

In females, prevalence of xerostomia was significantly higher in the 18-29-year-old age group, and besides, the UWS flow rate was significantly decreased in MHS females in this age group compared to 
NS or LIS groups. Some studies found no correlation between xerostomia and decreased whole saliva flow rates in smokers $[3,25,26]$, while other studies suggested that long term smoking results in lower salivary output $[18,27,29,32]$. Our results also support that heavy smoking may decrease salivation and contribute to the development of xerostomia and other sicca symptoms. However, the appearance of sicca symptoms in the affected organs may vary with age and other oral- and systemic health factors. Fatigue was also a significant subjective symptom in the male 30-39-year-old age group, which can be in connection with a number of different reasons: increased stress level, high level of heavy smoking, and furthermore, dry mouth. Dysphagia was significantly higher among male smokers in the 60+ age group. Since xerostomia did not differ significantly in the older age groups by smoking status, some other reasons might affect it, like edentulousness or tobacco smoke induced inflammation of the mucosa, although these assumptions need more investigation. Dysgeusia showed to be a significant sicca symptom in the female smoker 60+ age group. Since neither greater xerostomia prevalence nor decreased salivation could be detected in this group, a possible reason for gustatory disturbance could be the long-term tobacco smoke exposure causing changes in taste buds' forms, quantity and vascularization [40]. Contrary to the findings of Sendecka et al., xerophthalmia and additional burning and itching of the eyes were more common in the non-smoker female elderly participants $(60+$ age group) than in smokers. It suggests that other factors than smoking may cause these symptoms [41]. Our study explored that cigarette smoking might cause intraoral sicca symptoms like dysphagia and dysgeusia via other ways than provoking oral dryness. Further studies are needed to obtain a clearer explanation for our results regarding intra- and extraoral sicca symptoms other than oral dryness. Future studies should assess whether sicca symptoms have associations with provocative or inflammatory effects of tobacco smoke.

\section{Conclusions}

This study highlighted that high intensity of smoking may cause xerostomia, a decrease in the UWS flow rate, and an increase in palatal saliva flow rate in some age groups. However, other sicca symptoms were mostly unrelated to the presence of dry mouth. Besides regular dental and stomatooncological screening during dental checkups [42], it is recommended for dentists to routinely assess the smoking status of their patients and possible oral dryness symptoms of smokers. Moreover, dental healthcare professionals should be further encouraged to educate patients about the harmful oral health effects of smoking, in order to support cessation strategies to prevent adverse dental and oral consequences of these conditions [43].

\section{References}

1. SREEBNY LM, Int. Dent. J., 50, nr. 3, 2000, p. 140. DOI:10.1111/j.1875-595x.2000.tb00554.x.

2.STEFANESCU AM, SCHIPOR S, PAUN D, DUMITRACHE C, BADIU C, Acta Endocrinol., 7, nr. 4, 2011, p. 431. DOI:10.4183/aeb.2011.431.

3.FENOLL-PALOMARES C, MUÑOZ MONTAGUD JV, SANCHIZ V, HERREROS B, HERNÁNDEZ V, MÍNGUEZ M, BENAGES A, Rev. Espanola Enfermedades Dig., 96, nr. 11, 2004, p. 773. DOI:10.4321/s1130-01082004001100005.

4.SREEBNY LM. Xerostomia: diagnosis, management and clinical complications. In: EDGAR WM, O'MULLANE DM. (eds.) Saliva and oral health. 2. ed. London: British Dental Ass; 1996, p.43.

5. MÁRTON K, MADLÉNA M, BÁNÓCZY J, VARGA G, FEJÉRDY P, SREEBNY L, NAGY G, Oral Dis., 14, nr. 5, 2008, p. 472. DOI:10.1111/j.1601-0825.2007.01404.x.

6.SHIP JA, FOX PC, BAUM BJ, J. Am. Dent. Assoc., 122, nr. 3, 1991, p. 63. DOI:10.14219/ jada.archive.1991.0098.

7.VILlA A, CONNELL CL, ABATI S, Ther. Clin. Risk Manag., 11, 2015, p. 45. DOI:10.2147/ TCRM.S76282.

8. SCULLY C, Oral Dis., 9, nr. 4, 2003, p. 165. DOI:10.1034/j.1601-0825.2003.03967.x. 
9. BERTRAM U, Acta Odontol. Scand., 25, nr. Suppl 49, 1967, p. 1.

10.PATINEN P, AINE L, COLLIN P, HIETANEN J, KORPELA M, ENCKELL G, KAUTIAINEN H, KONTTINEN YT, REUNALA T, Oral Dis., 10, nr. 6, 2004, p. 330. DOI:10.1111/j.16010825.2004.01048.x.

11.SREEBNY L, BÁNÓCZY J, BAUM BJ, EDGAR WM, EPSTEIN J, FOX PC, LARMAS M, Int. Dent. J., 42, nr. 4, 1992, p. 291.

12. ***U.S. DEPARTMENT OF HEALTH AND HUMAN SERVICES. The Health Consequences of Smoking - 50 Years of Progress: A Report of the Surgeon General. GA: U.S. Department of Health and Human Services, Centers for Disease Control and Prevention, National Center for Chronic Disease Prevention and Health Promotion, Office on Smoking and Health, 2014.

13.DYASANOOR S, SADDU SC, J. Clin. Diagn. Res., 8, nr. 1, 2014, p. 211. DOI:10.7860/JCDR/ 2014/6650.3846.

14. SINGH M, YADAV P, INGLE N, INGLE E, KAUR N, J. Indian Assoc. Public Health Dent., 13, nr. 1, 2015, p. 11. DOI:10.4103/2319-5932.153549.

15. FERRAGUT JM, DA CUNHA MR, CARVALHO CAF, ISAYAMA RN, CALDEIRA EJ, Arch. Oral Biol., 56, nr. 6, 2011, p. 580. DOI:10.1016/j.archoralbio.2010.11.017.

16. PETRUŠIĆ N, POSAVAC M, SABOL I, MRAVAK-STIPETIĆ M, Acta Stomatol. Croat., 49, nr. 4, 2015, p. 309. DOI:10.15644/asc49/4/6.

17. KHAN GJ, MEHMOOD R, SALAH-UD-DIN, IHTESHAM-UL-HAQ, J. Ayub Med. Coll. Abbottabad, 15, nr. 4, 2003, p. 37.

18. KANWAR A, SAH K, GROVER N, CHANDRA S, SINGH R, Eur. J. Gen. Dent., 2, nr. 3, 2013, p. 296. DOI:10.4103/2278-9626.116017.

19. BARYLKO-PIKIELNA N, PANGBORN RM, SHANNON IL, Arch. Environ. Health., 17, nr. 5, 1968, p. 731. DOI:10.1080/00039896.1968.10665313.

20. PANGBORN RM, SHARON IM, Physiol. Behav., 6, nr. 5, 1971, p. 559. DOI:10.1016/00319384(71)90205-8.

21. ZHANG GH, MELVIN JE, Proc. Soc. Exp. Biol. Med., 207, nr. 3, 1994, p. 292. DOI:10.3181/00379727-207-43819.

22. IIDA T, ONO K, INAGAKI T, HOSOKAWA R, INENAGA K, Auton. Neurosci. Basic Clin., 161, nr. 1-2, 2011, p. 81. DOI:10.1016/j.autneu.2011.01.003.

23. ELIASSON L, BIRKHED D, HEYDEN G, STRÖMBERG N, Arch. Oral Biol., 41, nr. 12, 1996, p. 1179. DOI:10.1016/s0003-9969(96)00091-x.

24. AXELSSON P, PAUlANDER J, LINDHE J, J. Clin. Periodontol., 125, nr. 4, 1998, p. 297. DOI:10.1111/j.1600-051x.1998.tb02444.x.

25. SCHEIN OD, HOCHBERG MC, MUÑOZ B, TIELSCH JM, BANDEEN-ROCHE K, PROVOST T, ANHALT GJ, WEST S, Arch. Intern. Med., 159, nr. 12, 1999, p. 1359. DOI:10.1001/ archinte. 159.12.1359.

26. NORLÉN P, OSTBERG H, BJÖRN AL, Community Dent. Oral Epidemiol., 19, nr. 5, 1991, p. 296. DOI:10.1111/j.1600-0528.1991.tb00171.x.

27. ANTTILA SS, KNUUTTILA ML, SAKKI TK, Psychosom. Med., 60, nr. 2, 1998, p. 215. DOI:10.1097/00006842-199803000-00018.

28. IBRAHEEM LM, DHAFER AM, Adv. Res. J. Multidiscip. Discov., 32, nr. 8, 2018, p. 41.

29. RAD M, KAKOIE S, NILIYE BROJENI F, POURDAMGHAN N, J. Dent. Res. Dent. Clin. Dent. Prospects., 4, nr. 4, 2010, p. 110. DOI:10.5681/joddd.2010.028.

30. THOMSON WM, LAWRENCE HP, BROADBENT JM, POULTON R, Health Qual. Life Outcomes., 4, nr. 86, 2006. DOI:10.1186/1477-7525-4-86.

31. BILLINGS RJ, PROSKIN HM, MOSS ME, Community Dent. Oral Epidemiol., 24, nr. 5, 1996, p. 312. DOI:10.1111/j.1600-0528.1996.tb00868.x. 
32. JOHANSSON A-K, JOHANSSON A, UNELL L, EKBÄCK G, ORDELL S, CARLSSON GE, Eur. J. Oral Sci., 117, nr. 1, 2009, p. 13. DOI:10.1111/j.1600-0722.2008.00597.x.

33. BOULOS DNK, LOFFREDO CA, EL SETOUHY M, ABDEL-AZIZ F, ISRAEL E, MOHAMED MK, Nicotine Tob. Res., 11, nr. 2, 2009, p. 134. DOI:10.1093/ntr/ntp016.

34. HAMADA T, KAWAZOE Y, SEKINO K, NAGASAWA T, TSURU H, J. Dent. Res., 53, nr. 4, 1974, p. 944. DOI:10.1177/00220345740530043701.

35.ELIASSON L, BIRKHED D, CARLÉN A, Arch. Oral Biol., 54, nr. 3, 2009, p. 263. DOI:10.1016/j.archoralbio.2008.09.001.

36.ELIASSON L, CARLÉN A, Eur. J. Oral Sci., 118, nr. 5, 2010, p. 435. DOI:10.1111/j.16000722.2010.00766.x.

37.NIEDERMEIER W, HUBER M, FISCHER D, BEIER K, MULLER N, SCHULER R, BRINNINGER A, FARTASCH M, DIEPGEN T, MATTHAEUS C, MEYER C, HECTOR MP, Gerodontology., 17, nr. 2, 2000, p. 104. DOI:10.1111/j.1741-2358.2000.00104.x.

38. CSELKÓ Z, KOVÁCS G, HORVÁTH I. A dohányzás helyzete Magyarországon. In: TOKAJI K (ed.) Európai lakossági egészségfelmérés, 2014. Központi Statisztikai Hivatal, Budapest, 2018, pp. 85112.

39. PEJČIĆ A, OBRADOVIĆ R, KESIĆ L, KOJOVIĆ D, Med. Biol., 14, nr. 2, 2007, p. 53.

40. DA RÉ A, GURGEL L, BUFFON G, MOURA W, MARQUES VIDOR D, MAAHS M, Int. Arch. Otorhinolaryngol., 22, nr. 1, 2018, p. 081. DOI:10.1055/s-0036-1597921.

41. SENDECKA M, BARYLUK A, POLZ-DACEWICZ M, Przegl. Epidemiol., 58, nr. 1, 2004, p. 227.

42.MENSCH K, SZARKA K, MENSCH H, DOBAI A, MAGYAR Z, PACURAR M, VARTOLOMEI AC, MANUC D, DOBO NAGY C, Rev. Chim., 69, (10), 2018, 2781.

43. FAZAKAS Z, NEMES-NAGY E, FOGARASI E, PREG Z, LASZLO MI, KELEMEN H, GERMAN-SALLO M, BALAZS P, SZEKELY M, NIMIGEAN VR, FOLEY K, ABRAM Z, KIKELI PI, Rev. Chim., 70, (6), 2019, 2099. DOI:10.37358/RC.19.6.7283. 